This item was submitted to Loughborough's Research Repository by the author.

Items in Figshare are protected by copyright, with all rights reserved, unless otherwise indicated.

\title{
Young entrepreneurs in the mobile telephony sector in Ghana: From necessities to aspirations
}

\section{PLEASE CITE THE PUBLISHED VERSION}

https://doi.org/10.1080/15228916.2017.1339252

\section{PUBLISHER}

(C) Taylor \& Francis

\section{VERSION}

AM (Accepted Manuscript)

\section{PUBLISHER STATEMENT}

This work is made available according to the conditions of the Creative Commons Attribution-NonCommercialNoDerivatives 4.0 International (CC BY-NC-ND 4.0) licence. Full details of this licence are available at: https://creativecommons.org/licenses/by-nc-nd/4.0/

\section{LICENCE}

CC BY-NC-ND 4.0

\section{REPOSITORY RECORD}

Afutu-Kotey, Robert L., Katherine V. Gough, and George Owusu. 2019. "Young Entrepreneurs in the Mobile Telephony Sector in Ghana: From Necessities to Aspirations". figshare. https://hdl.handle.net/2134/26427. 
Young entrepreneurs in the mobile telephony sector in Ghana: From necessities to aspirations

Robert Afutu-Kotey, Katherine V. Gough and George Owusu

Published in Journal of African Business

http://dx.doi.org/10.1080/15228916.2017.1339252. 


\begin{abstract}
Despite increasing research interest in the mobile telephony sector, only a few studies have devoted attention to informal businesses in the sector. Using qualitative field data collected on young mobile telephony entrepreneurs in Accra, this paper argues that despite the businesses being 'informal', they cannot be dismissed as 'necessity' enterprises unworthy of support. On the contrary, many young entrepreneurs have aspirations which are influencing their desire to stay in business. The article thus questions the bifurcated nature of entrepreneurial motivations, using the burgeoning mobile telephony sector as a case study, and draws out implications for policy support for youth-run businesses in the informal sector generally.
\end{abstract}

Keywords: Young people, entrepreneurship, motivations, informal businesses, mobile telephony, Ghana 


\section{Introduction}

Entrepreneurship has been identified by policy makers and international organisations as a panacea to the youth employment challenge and as having the potential to promote economic growth in sub-Saharan Africa (SSA) (Africa Commission, 2009; Gough \& Langevang, 2016; ISSER, 2013; UNDP, 2004). These calls for greater entrepreneurship are being made notwithstanding the many young people who are already engaged in various forms of entrepreneurship, especially in the informal economy. The entrepreneurship policy calls are, therefore, being made under the assumption that the majority of informal economy businesses are run by 'necessity-driven' entrepreneurs who go into entrepreneurship due to lack of better employment prospects elsewhere. This is contrary to 'opportunity entrepreneurs' who are considered to go into business because they identify opportunities, possess growth intentions, and either contribute or possess the potential to contribute substantially to economic development (Singer et al., 2015).

Over the past two decades, an area that has attracted many young people through entrepreneurial activities is the mobile telephony sector. Liberalisation of the telecommunications sector in the 1990s in many countries in SSA (including Ghana) opened avenues for entrepreneurial activities in the mobile telephony sector, which were previously non-existent. Africa currently has over 350 million mobile phone subscribers, and the subscriber base is growing faster than anywhere else in the world, leading some to describe Africa as "a crucible for mobile phone innovation and entrepreneurship" (Etzo \& Collender, 2010, p. 657). As the subscriber base has increased, a large informal economy offering support services to the sector has emerged. In Ghana and many other SSA countries, the support services sector is dominated by young people involved in informal activities, such as sales and distribution of mobile phones, accessories and airtime, mobile telephony repairs and technical support, and mobile money transfer services.

Although there has been considerable research on the mobile telephony sector in recent times, the majority of these studies focus on the uses to which people put their phones, while others have looked at the impact of mobile phones on people's businesses and social relations (Boadi et al., 2007; Overå, 2008; Brouwer, 2010; Essegbey \& Frempong 2011; Porter et al., 2012; Lal Dey et al., 2013). A few studies have also documented the activities of solo entrepreneurs who import mobile phones from Hong Kong to Africa (Yu \& Kwan, 2015). However, very little is known about the young people involved in the informal mobile telephony support sector. 
Moreover, knowledge about the motivation driving these young people into informal entrepreneurial activities in the fast growing digital economy is missing. This notwithstanding, there is a growing body of literature that has questioned the necessity/opportunity divide which has long characterised the entrepreneurship motivation literature (Aidis et al., 2007; Langevang et al., 2012; Smallbone \& Welter, 2003; Snyder, 2004; Williams 2008; Williams \& Youssef, 2014). This paper assesses how applicable this emerging literature is within the Ghanaian informal economy context, using the mobile telephony sector as a case. By so doing, the paper contributes to the informal entrepreneurship motivation discourse by bringing into perspective the motivation behind business establishment among young people in the burgeoning informal digital economy in Ghana.

Before proceeding with the theoretical, methodological and analytical sections, it is appropriate to define entrepreneurship, young people and the informal economy in order to conceptually position the article. In lieu of the lack of consensus on what precisely constitutes entrepreneurship among academicians and the different definitions that have ensued (Kirzner, 1973; Naudé, 2008; Schumpeter, 1961; Wennekers \& Thurik, 1999), Naudé’s (2008) occupational definition of entrepreneurship is employed, which focuses on self-employment, combined with aspects of the Global Entrepreneurship Monitor (GEM) definition of entrepreneurship, which emphasises self-employment and owner-managed businesses. ${ }^{1}$ Entrepreneurship in this article is defined to involve informal self-employed, owner-managed and other small businesses in the mobile telephony sector that are run by young people. The informal economy has been defined to consist of "economic activities that occur outside of formal institutional boundaries but which remain within informal institutional boundaries for large segments of society” (Webb et al., 2013, p. 1). It therefore includes a range of selfemployed persons, who mainly work in unincorporated small or unregistered entities (Chen, 2012). The majority of the young entrepreneurs operating businesses in the mobile telephony sector are mostly self-employed with complete control or autonomy over their enterprises. However, some employ one or possibly two additional workers, and the enterprises are largely not legally incorporated as enterprises. As a result, the distinction between the enterprise on the one hand and the entrepreneur on the other with respect to legal liability, accounts, and assets is

\footnotetext{
${ }^{1}$ The Global Entrepreneurship Monitor (GEM) project is an annual assessment of entrepreneurial activity, aspirations and attitudes of individuals across a wide range of countries
} 
not very clear. Furthermore, the enterprises run by the youth are not illegal in the strict sense of deliberately avoiding existing regulations or laws, rather, these enterprises do not have a legal status that is separate from the young people who own the businesses.

The terms ‘young people' and 'youth' are often used interchangeably in some of the literature, while the term 'young people' has been used to refer to children and youth combined (ISSER, 2010). In this article the concepts ‘youth' and 'young people' are used interchangeably to refer to the 15-35 age group as defined by the National Youth Policy of Ghana (Government of Ghana/Ministry of Youth and Sports, 2010), and an age range that is commonly used to define youth across SSA.

\section{Entrepreneurial motivations - Theoretical perspectives}

The entrepreneurship literature distinguishes two broad approaches in the study of motivations for start-ups. The first places emphasis on examining the personal attributes that drive individuals into establishing businesses (Gartner, 1989; Tan, 2001). Gartner (1989) referred to this approach as 'traits'. Accordingly, this body of literature places considerable emphasis on personal attributes such as the desire for achievement, risk-taking behaviour, ambitions, desire for independence, and taking responsibility (Lee \& Chan, 1998; Tan, 2001). The second approach focuses on environmental factors or what has become popularly known as push-pull factors in explaining entrepreneurship motivation (Benzing \& Chu., 2009; Watson et al., 1998). Taormina and Lao (2007) noted that 'pull' factors are those driving forces that make the desire for start-up attractive, such as the desire to have one's own time at work. The "push" factors, on the other hand, are the factors that impel a person to start a business in order to avoid an undesirable situation such as unemployment.

Influenced by the environmental push-pull thesis, the entrepreneurship literature has been classified broadly into two main divisions in terms of motivation for start-up: survivalist and growth-oriented enterprises (Gomez, 2008; Kanothi, 2009; Langevang et al., 2012; Rosa et al., 2006). Survivalist enterprises comprise businesses established mostly by the poor with survival as the motive; most people involved in these businesses have limited employment options (Rosa et al., 2006). Growth-oriented enterprises are distinct from survivalists in terms of capacity, motive and size. Among growth-oriented enterprises, there is a clear motivation to grow and reinvest earnings into the enterprise. Additionally, growth-oriented enterprises, among others, place a lot of attention on hiring additional staff, sourcing supplies, investing 
available capital and applying specialised skills (Berner et al., 2012; Gomez, 2008). Generally, the literature characterises most enterprises in the developing world, especially Africa as survivalist enterprises, while those in the developed world are classified as growth-oriented (Langevang et al, 2012; Naude, 2011; Rosa et al., 2006). A basic assumption is that most entrepreneurs in Africa start their businesses on their own because they cannot find jobs elsewhere and, therefore, develop businesses that tend to be survivalist in orientation (Frese \& de Kruif, 2000). Furthermore, there is a gendered dimension to the entrepreneurship motivation discourse where women are observed to dominate in the informal or survivalist sector with limited growth prospects (Babah Daouda et al., 2016).

The survivalist and growth-oriented thesis has been advanced further by the GEM project to measure motivation for establishing businesses among entrepreneurs across the globe. The GEM broadly characterises survivalist activities as necessity-driven without clear objectives or prospects for growth, while growth-oriented enterprises are classified as opportunity driven (Kelley et al., 2011; Singer et al., 2015; Yankson, et al., 2011). Hence, opportunity entrepreneurship is considered to be motivated by the identification and exploitation of good business opportunities while necessity driven entrepreneurship is motivated by the absence of any other work opportunities. Under this dichotomy, the self-employed without any better alternative work options are noted to constitute a large segment of necessity entrepreneurs who seem to predominate in the developing or low income countries. Within these countries, employment capacity in the private and public domain is limited, and there is the absence of social welfare benefits for the unemployed including the youth (Yankson et al., 2011). Consequently, many young people have to create their own jobs by starting a business in order to survive and support themselves and their households (Gough \& Langevang, 2016; ISSER, 2010). In SSA for instance, about a third of young entrepreneurs are noted to be driven by necessity motives compared to Asia Pacific and South Asia where 80 per cent of young entrepreneurs are driven by opportunity motives (Kew et al., 2013).

Furthermore, attempts have been made in a section of the entrepreneurship literature to link entrepreneurial start-up motivations with growth prospects or aspirations (Hessel et al., 2008; Langevang et al., 2012; Olomi, 2009). This linkage is established on the premise that necessitydriven entrepreneurs are less likely to have growth intentions or aspirations, compared to opportunity driven entrepreneurs. On the basis of this assumption, a distinction is made between necessity motivated entrepreneurs who are perceived to be survivalist in nature and 
often operate at subsistence levels in the informal economy on the one hand, and opportunity motivated or growth-oriented entrepreneurs who operate in the formal sector on the other hand (Gries \& Naudé, 2010; Naudé, 2011). The bifurcated nature of entrepreneurial motivations into a necessity-opportunity divide has been questioned in the literature in relation to entrepreneurs both in the formal sector (Aidis et al., 2007; Smallbone \& Welter, 2003) and informal sector (Snyder, 2004; Williams, 2008; Williams \& Youssef, 2014). The main argument in this growing body of literature is that some of the motivation factors do change with time, while some entrepreneurs start businesses in the informal economy because of identified opportunity and choice. Particularly for the informal economy, Williams (2008) observed motivations to shift from necessity-oriented in the early stages of the enterprise development to opportunityoriented as the business becomes more established, while Chen (2012) identified necessity in addition to choice as drivers of informality.

It is important to emphasize that the majority of studies that have questioned the bifurcated nature of entrepreneurial motivations into the opportunity-necessity divide have focused on enterprises in Europe (Aidis et al., 2007; Smallbone \& Welter, 2003; Williams \& Youssef, 2014) and the Americas (Snyder, 2004; Williams, 2008) with little coverage given to the SSA situation and particularly among young people (though see Langevang et al. 2011 for an exception). In view of the above, this article assesses the applicability of the emerging informal entrepreneurship motivation literature, which has questioned the necessity-opportunity duopoly. This is done by analyzing the motivations of young entrepreneurs in the fast growing informal digital economy in Accra, Ghana. Recognising the rationale for going into business among these young people becomes crucial for understanding and stimulating entrepreneurship among the youth. This is especially so as entrepreneurship has been identified and is being promoted as a way of addressing the youth unemployment challenge in the SSA region.

\section{Methodological approach}

This article is based on a broader study on youth entrepreneurship in the mobile telephony sector in the Greater Accra Metropolitan Area, which employed a multiple research methodological approach with primary data collected over the period of December 2010 to January 2013 (Afutu-Kotey, 2013). Qualitative data from the broader study, involving a mapping exercise, life trajectory interviews and biographical interviews, are drawn on here. The mapping exercise commenced the data collection and involved field visitation and observations in localities with a concentration of mobile telephony businesses within Accra. 
Five study localities were selected following the mapping exercise - Kwame Nkrumah Circle, Madina, Kaneshie Lorry Station, Tema Lorry Station and the Legon-Madina road. Justification for the selection of these localities was the heavy concentration of informal mobile telephony businesses and the diversity of these businesses in these localities (Afutu-Kotey, 2016).

Biographical interviews were conducted with 25 young people aged 15-35 years, who were operating mobile telephony businesses within the study localities, to discover their motivations for going into business at various stages of their life courses. These young people were purposively selected from the list of entrepreneurs generated for the broader study using two key criteria. First, to ensure participants had the depth of knowledge necessary to inform the study, they all had at least two years of operating in the mobile telephony sector. Second, with the objective of identifying manifestations of opportunity, necessity and other motivation variants in the narratives of respondents, the young people were sampled on the basis of potential representation of opportunity, necessity and other motivation factors (see Patton, 2002). After conducting 25 biographical interviews, we had reached the point of saturation where no new substantive information was emerging, hence the decision was made not to conduct any more (see Miles \& Huberman, 1994). Of the young people selected, eight were female and 17 male, whilst 12 had completed the senior high school education, 10 had basic school education, two had completed a higher national diploma and one was without any educational qualification. The interviews were conducted at the business premises of respondents and lasted between 55 and 70 minutes (see Table 1). They focused on the link between the life course of the young people and their motivations for going into, and staying in business, in addition to the future aspirations of the young people as far as the life course and business are concerned. In order to protect the anonymity of respondents, all the names used in the article are pseudonyms.

Table 1: Biographical interviewees, interview duration and primary motivation factor

\begin{tabular}{lll}
\hline Persons interviewed & Duration & Primary motivation \\
\hline Kojo & 64 minutes & Opportunity \\
Charles & 70 minutes & Opportunity \\
Eric & 61 minutes & Opportunity \\
Alex & 65 minutes & Opportunity \\
Agya & 64 minutes & Opportunity \\
Sam & 55 minutes & Opportunity \\
Kofi & 58 minutes & Opportunity
\end{tabular}




\begin{tabular}{lll} 
David & 67 minutes & Opportunity \\
Seth & 65 minutes & Neither necessity nor opportunity \\
Prince & 60 minutes & Neither necessity nor opportunity \\
Efe & 59 minutes & Neither necessity nor opportunity \\
Michael & 68 minutes & Neither necessity nor opportunity \\
Bernard & 69 minutes & Neither necessity nor opportunity \\
Patience & 66 minutes & Necessity \\
Jane & 70 minutes & Necessity \\
Okai & 68 minutes & Necessity \\
Sowah & 57 minutes & Necessity \\
Obeng & 61 minutes & Necessity \\
Sedro & 55 minutes & Necessity \\
Gloria & 63 minutes & Necessity \\
Boakye & 68 minutes & Necessity \\
Patricia & 63 minutes & Necessity \\
Simon & 59 minutes & Both necessity and opportunity \\
Stephen & 66 minutes & Both necessity and opportunity \\
Kelly & 56 minutes & Both necessity and opportunity \\
\hline
\end{tabular}

Source: Extracted from Biographical Life Course Interviews, October 2012 to January, 2013

In addition to the biographical interviews, life trajectory studies were conducted with 15 young people, eight out of whom were recruited during the mapping exercise and the remaining seven were selected from a group of young people who had been recruited by a non-governmental organisation (NGO) to undergo training on mobile phone repairs. Recruitment of these young people for the training programme coincided with the onset of the data collection, hence we were able to monitor the activities of these young people throughout their training, which lasted six months, and their life course after the training. Similar to the biographical interviews, these young people were also selected purposively with their knowledge base or experience influencing the selection criteria, especially for the eight who were already established in the sector, all of whom had been operating their businesses for at least two years (Kwame Nkrumah Circle 4, Madina 2, Tema Lorry Station 1 and Kaneshie Station 1). Like the biographical interviews, the sampling from the mobile phone repair-training programme was done to obtain a potential representation of opportunity, necessity and other motivation variants (Patton, 2002). The life course of these individuals and their businesses were monitored over a period of three years through interviews that were conducted every three months. The life trajectory studies were used to monitor the changing trends with respect to business activities and the motivation and aspirations of the young people. The questions asked were similar to those used for the biographical interviews (see Table 2), however, as multiple interviews were conducted with each participant in the life trajectory studies, it was possible to investigate 
motivations for being in business at multiple points in time and explore the changing nature of motivations among young people. Furthermore, due to the rapport that was developed with the participants over time, through this method information was revealed which otherwise would not have been forthcoming. It is worth noting, however, that three of the participants dropped out during the life trajectory studies and one unfortunately died.

Table 2: Extract of interview guide used for the biographical interviews

\begin{tabular}{|c|c|}
\hline Issues & Interview questions \\
\hline Life chapters & $\begin{array}{l}\text { We would like you to begin by thinking about your life as a story. Think } \\
\text { about your life story as having at least a few different chapters. What might } \\
\text { those chapters be? I would like you to describe for me each of the main } \\
\text { chapters of your life story. If you can, give each chapter a name and describe } \\
\text { briefly the overall contents in each chapter. }\end{array}$ \\
\hline
\end{tabular}

Critical I am going to ask you about some specific life events (peak experience, nadir events experience and turning point) in your life course. For each event, describe in detail shaping the what happened, where you were, how you were involved, what you did, and what life course you were thinking. Also, try to convey what impact this key event has had in your (including life story and what this event says about who you are as a person at present.

business)

Life course Now that you have given us an outline of the chapters in your story and the and business key events that had shaped your life course over the years, we would like you to concentrate on your business. Why did you decide to go into this business? How did you start this business? What is your main reason for going into this business?

Aspirations Tell me about your future plans and aspirations for this business. Do you for the future intend staying in this business? Why do you intend staying in this business? Do you intend changing the location/products of your business? How are you going to go about this? Do you intend leaving this business? Why? What do you plan to do instead? How will you achieve this?

Source: Extracted from Biographical Life Course Interviews, October 2012 to January, 2013

With the consent of interviewees, both the biographical and life course interviews were audio recorded and a verbatim transcription subsequently undertaken. In addition, field notes were also taken during each phase of the data collection. Transcripts of the interviews and field notes were read through several times in order to get a good grasp of the data at the start of the analysis process. After these detailed readings, the qualitative data was described, classified and interpreted. Codes were used, which involved reducing the data set into meaningful segments, assigning names to these segments, categorizing the various themes within the data, and then assigning codes to broader categories or themes. Interpretation was conducted in relation to the existing literature. 


\section{Entrepreneurial motivations in the mobile telephony sector}

In this section, we present findings from the textual analysis of the biographical and life course interviews conducted with the young mobile telephony entrepreneurs. The analysis of the biographical narratives of the youth revealed 10 different motivation factors behind the decision for business establishment in the mobile telephony sector (see Table 3). The most recurrent motivation factor is the passion that the young people have for the mobile phone, which received 11 counts followed by the desire to take advantage of an acquired skill or talent and exploiting identified opportunity, both of which received nine counts each. Other motivation factors identified in the narratives include saving money for school (8 counts), quit a low paying job (7 counts), migration (6 counts), social networks (5 counts), building capital for future (5 counts), no better job opportunities (5 counts) and difficult economic conditions (5 counts) (Table 3). In the following section, an expatiation of each of these themes as extracted from the narratives of the youth is presented.

Table 3: Motivation factors and number citations in narratives

\begin{tabular}{lcc}
\hline Motivation factors & $\begin{array}{c}\text { Number of respondents } \\
\text { citing factor }\end{array}$ & $\begin{array}{c}\text { Necessity-opportunity } \\
\text { duopoly }\end{array}$ \\
\hline $\begin{array}{l}\text { Passion for mobile phone } \\
\text { Take advantage of acquired skill or }\end{array}$ & 9 & Opportunity \\
talent & 9 & Opportunity \\
Exploit identified opportunity & 8 & Opportunity \\
Saving money for school & 7 & Necessity \\
Quit a low paying job & 6 & Necessity \\
Migration & & Neither opportunity \\
& 5 & nor necessity \\
Network of relations & 5 & Neither opportunity \\
Build capital & 5 & nor necessity \\
No better job opportunities & 5 & Necessity \\
Difficult economic conditions & Necessity \\
\hline Source: Extracted from Biographical Life Course Interviews October 2012 to January, 2013
\end{tabular}

Source: Extracted from Biographical Life Course Interviews, October 2012 to January, 2013 
The most frequently cited motivation factor, strong passion and interest that the young people have for the mobile phone, is often linked to other motivation factors such as taking advantage of acquired skills or talent and identified business opportunity. The narratives of Kojo and Charles are illustrative of the strong passion and interest intertwined with other motivation factors that underpin the decision of young people to go into business in the mobile telephony sector. Kojo is a 28 year old who runs a phone repair business. After completing senior high school (SHS), he went into apprenticeship training in computer hardware technology. He explained that although he occasionally works as a computer technician, his main line of business at present is mobile phone repair, which he was motivated to enter because of his strong passion for mobile phones. Kojo explained that, "I am very much interested in mobile phones and because of my skills and knowledge in computers, I got interested in repairing mobile phones.” Similarly, Charles, a 32 year old who trades in mobile phones stated his motivation for going into business as follows:

I have strong interest in mobile phones and I'm very fascinated by the device. I got a job with Vodafone and we were promoting products of the company. ${ }^{2}$ While working for Vodafone, I realised that there are opportunities in the phone business to make money. Also, the Vodafone job was on contract and I've always wanted to establish my own business. After making a little savings, I quit [Vodafone] to establish my own business.

In addition to the combination of passion and opportunity, Charles's statement demonstrates how some of the young people are motivated to move from a formal economy job to selfemployment in the informal economy as a result of identifying an opportunity in the latter. In many instances, this strong sense of passion and interest for the mobile phone is often influenced by the fact that the youth see the mobile phone as a technological device for their generation. Kojo noted in this regard that "the mobile phone is for our generation and it has come to stay. We have to make the most of the technology.” Making the most of the technology gives indications of opportunity driven inclinations for business establishment in the informal mobile telephony sector.

Some of the youth indicated that they were motivated to establish their businesses as a result of an opportunity identified in the mobile telephony sector which they are exploiting. Identifying a business opportunity and exploiting as such is exemplified by the case of 33 year old Eric

\footnotetext{
${ }^{2}$ Vodafone is currently the third largest operator with respect to customer base in Ghana
} 
who started a business in the mobile telephony sector by importing mobile phone accessories and diversified this business by adding mobile phone handset imports. He explained the motivation behind establishing his business as follows:

When the mobile phone companies started introducing phones into the system, I realised that once they were bringing their phones, people will definitely need the accessories. I paid particular attention to the phones brought into the market by the mobile phone companies and will go [abroad] and bring accessories for these phones.

Eric was engaged in a business outside the mobile telephony sector before identifying an opportunity in the mobile phone and accessories market. He closely observed the trends in the sector and identified and exploited opportunities in the areas where his business would flourish. Having run a mobile telephony business for a while, he continues to explore further opportunities in the sector. Continuously identifying and exploiting opportunities in the sector constitute a motivation factor that keeps some of the young people in business. An instance in this regard is 24 year old Alex who trades in mobile phone accessories. He stated as follows:

Because we are many over here, the wide variety of goods you have, the more people purchase from you and you are able to make more sales. Someone may be looking for a particular [phone] charger and if you have a lot of goods, the person might buy the charger from you. In case I don't have that particular charger, I record it in my notebook and I make sure that the next time I go to buy items, I get that particular charger. ${ }^{3}$

Alex meticulously records in a foolscap notebook his customers' requests for goods that he does not have in stock, in order to know which particular accessories are in demand. His ultimate objective is to help boost sales and stay in business. By meticulously studying market trends to identify opportunities in areas where there is demand for particular items or some particular kinds of services, Alex and Eric both revealed their motivations to stay in business.

For a section of the youth, their motivation to establish businesses in the mobile telephony sector is driven by a combination of previously acquired skills, low paying jobs and migration. The case of Simon best illustrates this complexity in motivation behind business establishment among the young people. Simon, a 34 year old trained electrician who worked with an electrical firm in Kumasi before quitting after four years as the "pay was not good enough”,

\footnotetext{
${ }^{3}$ This notebook is foolscap sized with about 150 pages and is just over 50 per cent complete.
} 
stated that "rather than sit there and waste my time, I will do something on my own." ${ }^{4}$ With this strong desire to do something on his own, Simon migrated from Kumasi to Accra. He explained his decision to establish a mobile phone repair business as follows:

Repairing phones is a talent I developed on my own due to my knowledge in electronics. When I came to Accra, I decided to go into the mobile phone repair business as people were buying phones and the China phones easily break down.

Simon did not migrate to Accra specifically to establish a mobile phone repair business, rather he moved with the objective of "doing something” for himself. After a few failed attempts to get an electrical job, he realised his talent for repairing mobile phones and he established a business in the sector. As this illustrates, Simon's case initially depicts inclinations of necessity driven motives as the electrical job he was doing prior to migrating to Accra was not rewarding with respect to income and he decided to look for another job which prompted the decision to migrate to Accra. After failing to secure an electrical job in Accra, he identified an opportunity in the mobile phone repair sector which he exploited using his knowledge in electronics. Even though Simon can be described as necessity or survivalist driven entrepreneur because he could not secure any better job opportunity (see Xavier et al., 2012; Singer et al., 2015), prior to establishing his mobile telephony business in Accra he identified an opportunity in the mobile phone repair business due to the ease with which Chinese made phones, which are the most popular in Ghana due to their low cost, break down. By recognising an opportunity in the phone repair sector and exploiting it, Simon could to a large extent be described as an opportunity motivated entrepreneur. This notwithstanding, the case provides an exposé of the complex nature of motivations behind business establishment and the extent to which the necessity-opportunity duopoly shields this complexity.

Motivation for going into business for some of the youth is not specific to a particular factor that remains constant but rather their motives change over time. The case of Obeng best demonstrates this changing nature of motivations for business establishment in the mobile telephony sector. Obeng is a 29 year old who dropped out of secondary school due to difficulties on the part of his parents to pay the cost of his education. He stated his motivation for establishing his mobile phone business as follows:

\footnotetext{
${ }^{4}$ Kumasi is the second largest city in Ghana
} 
The main reason is how to get something to live on and get a secured future for my children. I couldn't further my education because there was no help, but with this business in future when I give birth I can see my children through school.

Two key motivations stand out in Obeng's narrative - the desire to survive by getting "something to live on" and "the secured future of his children". Having established his mobile phone business because of the need to get something to live on, Obeng's case could best be described as necessity or survivalist driven. Obeng's prospects for securing a job became limited after dropping out of school, and the mere idea of staying home without a job motivated him to "Get something doing in order to survive" and establish a mobile phone business. Subsequently, however, Obeng's key motive for staying in the business has altered and his current reason is the need to secure a better future for his children, which he envisions, should be better than his. Thus, for a section of the youth, although they have a fundamental motive for establishing their businesses, this motive does not remain the same at all times but changes steadily over time.

Some youth are motivated to establish mobile telephony businesses because they need an avenue that will accord them the opportunity to save money to further their education. According to Sedro, who is 22 years old, "I am doing this business [airtime sales] because I want to save money in order to go back to school.” Business in the mobile phone sector for this group of young people is only a stop-gap which enables them to save an appreciable amount of money in order to further their education. Even those who are able to save and continue their education, do not entirely stop their business but rather run the business alongside schooling by leaving the business in the care of trusted relations during school hours. A typical example is Jane, aged 22, who trades in airtime. After completing her SHS exams, she did not have sufficient grades in order to proceed to the tertiary level. With the little support coming from her family to enable her rewrite some of her failed papers, Jane decided to establish an airtime business in order to support her education. She stated that, "My brother takes care of the business for me. I only come to take over after school.” Jane is fortunate enough to have a trusted relation who takes care of the business in her absence. For others, however, the lack of trust and suspicion of being exploited drives them to lock-up the business during school hours and reopen after school. This scenario was explicitly stated by Gloria (26 years old) who runs an airtime business: 
With this kind of work, if you don't get a good person to take care of the business in your absence, you will lose your money. I know people whose businesses have collapsed because they couldn't get a good person to take care of the business in their absence. Because of this, whenever I'm going for classes, I lock the business and reopen when I come back as I don't trust anyone to take care of the business in my absence.

Structural constraining factors can influence the decision to establish businesses in the mobile telephony sector among a section of the youth. Some structural constraining factors identified in the narratives include the generally difficult economic conditions (5 counts) in the country which offers limited opportunities for young people and the difficulties in securing employment (5 counts), especially for young people in the public and private formal sector. The case of Boakye exemplifies how structural constraints combine to influence young people's decision to establish businesses in the mobile telephony sector. Boakye is a 22 year old who completed junior high school (JHS), but currently trades in mobile phone accessories. He explained his motivation for going into business as follows: "There are no jobs for us [young people] to do so when you get something doing that can take care of you, you have to hold on to it well.” This motive exhibits necessity or survivalist driven inclinations for going into business among young people.

The network of relations (5 counts) of the young people was observed among the motivation factors driving the decision to establish business in the mobile telephony sector. Some established their businesses because they had a relation, such as a family, friend or an acquaintance who introduced them into the business. Seth, 23 years, who trades in airtime noted that, "My elder brother is in the airtime business and he introduced me into the business.” Similarly, Obeng's case introduced earlier also demonstrates the role the young people's social networks play in the decision to establish businesses in the mobile telephony sector. After dropping out of school, Obeng was introduced into the mobile phone sales business by his brother. Such young people initially enter the mobile telephony sector by working for their relations, which enables them to acquire the knowledge base and accumulate capital for establishing their own businesses.

The discussion so far has pointed to the multiple, complex and changing nature of motivations behind the establishment of businesses by young people in the mobile telephony sector. In the following section, the discussion is taken further by examining the aspirations and growth intentions of the youth with businesses in the mobile telephony sector. 


\section{Aspiration and growth intensions for business}

The overwhelming majority of the young people studied expressed positive growth intentions and aspirations for their businesses. These positive aspirations in order of frequency of occurrence in the narratives of the youth include the intention to acquire a bigger facility or premise for business (13 counts), growing business into importation and wholesale of mobile phones and related products (10 counts), and open new branches (10 counts). Other growth intentions include purchasing new equipment for running the business (6 counts) and acquire new skills that will help grow the business (5 counts).

A positive aspiration of the young people was captured in the narrative of Kelly (aged 23) who runs a table-top mobile phone business at the Kwame Nkrumah Circle. Kelly stated that, "I want to expand my business from this table into a shop.” For the young people who indicated having aspirations of moving into a bigger facility or premise, the ultimate goal is either to operate in a shop or a freight container, which are perceived to represent the higher echelons of the mobile telephony business, especially with respect to the facility of operation. Many of the youth who operate hand-held businesses, however, expressed the ambition of moving just a step further by acquiring a glass cabinet for their business. This again demonstrates positive growth aspirations as well as gradual progression regarding growth of business.

Other positive growth aspirations were observed in the narratives of Michael and Patience. Michael (27 years) who trades in phone accessories stated his aspiration for his business as follows: "My aspiration is to expand the business into wholesale for mobile phone accessories. I'd like to travel abroad to bring the phone accessories myself and sell them at the wholesale level.” Similarly, Patience (24 years) expressed her aspiration for her airtime business as follows: "First, I would like to grow the business into wholesale of airtime. I also want to obtain a store and introduce mobile money transfer in addition.” There is, therefore, a clear intention on the part of the majority of the young people to grow their businesses from the current size into a higher level operation. Since the majority of the young people expressed positive intentions of growing their businesses, they cannot be categorised as necessity entrepreneurs without growth prospects for their businesses, as the necessity/opportunity informal economy motivation duopolistic literature would suggest. 
Aside those with positive growth intentions for their businesses, there was a minority who do not have a clear intention or aspiration of growing their businesses. These are mostly young people who run their businesses with the objective of saving money in order to further their education. In the words of Efe (19 years) who deals in airtime, “I don't see my future in this business. I'm in this business to save money to go back to school. I can't school and do this work at the same time so when I go back to school, I'll stop.” A similar notion was observed in the narrative of Prince (23 years) who trades in phone accessories. Prince stated that, "This business is taking care of my schooling. When I finish school, I'll look for another job to do.” Although these individuals did not express the aspiration of growing their businesses, they cannot be dismissed as necessity driven entrepreneurs as the narratives show how they are in the mobile telephony sector by choice (Chen, 2012) and that when they save enough money to further their education, they will leave.

\section{Conclusions and policy implications}

This article has applied the emerging theorisation of entrepreneurial motivations in the informal economy literature, which has questioned the bifurcated division of entrepreneurial motivations into a necessity/opportunity dichotomy (Snyder, 2004; Williams, 2008; Williams \& Youssef, 2014). The article has demonstrated that there is no clarity on the dominance of a particular motivation factor that drives the establishment of a business among young people in the mobile telephony sector. There is clear evidence, however, of a complex and multiplicity of motivation factors that drive the establishment of business among the young people studied. Moreover, some of the motivation factors are not constant but change steadily over time, with experience and the reward that the business brings, thus confirming the observation by Snyder (2004) and Williams (2008) with respect to the shifting and fluid nature of motivations among some informal economy operatives. Aside the changing motivation pattern, the article observed the interconnected nature of motivations that drive some of the young people into business in the informal economy.

Thus, for the young people studied, it is difficult to state whether it is necessity or opportunity that drives their business establishments, as the necessity/opportunity duopoly would suggest. This is because both necessity and opportunity drivers were identified in addition to other factors such as migration, which cannot easily be categorised under the necessity-opportunity motivation divide. Furthermore, for some of the young people studied there were instances where they had more than one motivational factors, some of which were linked to each other. 
This shows how motivation is a highly complex phenomenon. Irrespective of their motivations for having a business, the young people studied demonstrated positive growth aspirations for their businesses, apart from those who were just running a business to pay for their education. By observing the fluid, diverse, complex and interconnected nature of motivation among the young people studied, this article thus joins the growing body of literature that has questioned the necessity/opportunity duopoly in the informal entrepreneurship literature (Aidis et al., 2007; Langevang et al., 2012; Smallbone \& Welter, 2003; Snyder, 2004; Rosa et al., 2006; Williams, 2008; Williams \& Youssef, 2014). An alternative understanding of the informal entrepreneurship motivation literature has been provided which runs contrary to the necessity/survivalist and opportunity/growth oriented thesis.

On the policy front, categorising entrepreneurs by way of necessity and opportunity has become important in influencing government policies and debate with respect to support for entrepreneurship (Langevang et al., 2012; Meager, 1996). The rationale is that necessity driven entrepreneurs do not contribute substantially to economic development and growth, hence are considered to be undeserving of support. As this article has highlighted, however, young people running informal businesses in cities across Africa may not be operating as necessity entrepreneurs. Support for these young entrepreneurs could help propel their businesses along the path of growth and employment generation thus making an important contribution to their national economies. 


\section{References}

Afutu-Kotey, R. L. (2013). Youth livelihoods and entrepreneurship in the mobile telephony sector in the Greater Accra Metropolitan Area. (Unpublished doctoral thesis). University of Ghana, Legon-Accra, Ghana.

Afutu-Kotey, R. L. (2016). Young entrepreneurs in the mobile telephony sector in Ghana. In K. V. Gough and T. Langevang (Eds.), Young Entrepreneurs in Sub-Saharan Africa. New York and London: Routledge.

Africa Commission. (2009). Realising the Potential of Africa's Youth: Report of the Africa Commission. Africa Commission.

Aidis, R., Welter, F., Smallbone, D., \& Isakova, N. (2007). Female entrepreneurship in transition economies: the case of Lithuania and Ukraine. Feminist Economics, 13(2), 157-183.

Babah Daouda, F., Ingenbleek, P. T., \& van Trijp, H. C. (2016). Step-Change: MicroEntrepreneurs' Entry into the Middle-Class Market. Journal of African Business, 17(2), 129-147.

Benzing, C. \& Chu, H. M. (2009). A comparison of the motivations of small business owners in Africa. Journal of Small Business and Enterprise Development 16, (1) 60-77.

Berner, E., Gomez, G., \& Knorringa, P. (2012). Helping a large number of people become a little less poor: The logic of survival entrepreneurs. European Journal of Development Research, 24(3), 382.

Boadi, R. A., Boateng, R., Hinson, R. \& Opoku, R. A. (2007). Preliminary insights into mcommerce adoption in Ghana. Information Development, 23(4), 253-265.

Brouwer, R. (2010). Mobile Phones in Mozambique: The Street Trade in Airtime in Maputo City. Science Technology \& Society, 15(1), 135-154.

Chen, M. A. (2012). The informal economy: Definitions, theories and policies. Women in informal economy globalizing and organizing: WIEGO Working Paper, 1. Manchester, WIEGO.

Essegbey, G. O., \& Frempong, G. K. (2011). Creating space for innovation-The case of mobile telephony in MSEs in Ghana. Technovation, 31(12), 679-688.

Etzo, S., \& G. Collender. (2010). The mobile phone "revolution” in Africa: Rhetoric or reality? African Affairs, 109 (437), 659-668.

Frese, M., \& de Kruif, M. (2000). Psychological success factors of entrepreneurship in Africa: A selective literature review. In Micro business owners in Africa: A new psychological approach, edited by M. Frese, Westport, CT: Greenwood Publishers.

Gartner, W. B. (1989). Some suggestions for research on entrepreneurial traits and characteristics. Entrepreneurship Theory Practice. 14 (1), 27 - 38.

Gomez, G. M. (2008). Development of micro enterprises into small and medium enterprises: Report prepared in Partnership for Learning. The Hague: Institute of Social Studies.

Government of Ghana/Ministry of Youth and Sports. (2010). National Youth Policy of Ghana: Towards an Empowered Youth, Impacting Positively on National Development, Ghana. Accra: GoG/MYS.

Gries, T., \& Naudé, W. (2010). Entrepreneurship and structural economic transformation. Small Business Economics, 34, 13-29.

Gough, K. V. \& Langevang, T. (Eds.). (2016). Young Entrepreneurs in Sub-Saharan Africa. New York and London: Routledge.

ISSER (Institute of Statistical, Social and Economic Research). (2013). Ghana Social Development Outlook 2012. Accra: ISSER.

ISSER (Institute of Statistical, Social and Economic Research). (2010). The State of the Ghanaian Economy in 2009. Accra: ISSER. 
Kanothi, R. N. (2009). The dynamics of entrepreneurship in ICT: Case of mobile phones downstream services in Kenya. Institute of Social Studies Working Paper No. 466, Hague: ISS.

Kew, J., Namatovu, R. Aderinto, R., \& Chigunta, F. (2013). Africa's young entrepreneurs: unlocking the potential for a brighter future. Global Entrepreneurship Research Association (GERA).

Kelley, D. J., Bosma, N. \& Amoros, J. E. (2011). Global Entrepreneurship Monitor: 2010 Global Report. London: GERA.

Kirzner, I. M. 1973. Competition and Entrepreneurship. Chicago: University of Chicago Press.

Lal Dey, B., Binsardi, B., Prendergast, R., \& Saren, M. (2013). A qualitative enquiry into the appropriation of mobile telephony at the bottom of the pyramid. International Marketing Review, 30(4), 297-322.

Langevang, T., Namatovu, R., \& Dawa, S. (2012). Beyond necessity and opportunity entrepreneurship: motivations and aspirations of young entrepreneurs in Uganda. International Development Planning Review, 34(4), 439-460.

Lee, J., \& Chan, J. (1998). Chinese entrepreneurship: a study in Singapore. The Journal of Management Development, 17 (2), 131-7.

Meager, N. (1996). From unemployment to self-employment. Labour market policies for business start-up. In G. Schmidt, J. O’Reilly and K. Schömann (Eds.), International Handbook of Labour Market Policy and Evaluation, 489-519, Cheltenham: Edward Elgar.

Miles, M. B., \& Huberman, A. M. (1994). Qualitative data analysis: An expanded sourcebook. Sage.

Naudé W. (2008). Entrepreneurship in Economic Development. Research Paper No. 2008/20, UNU-WIDER.

Naudé, W. (2011). Entrepreneurship is not a binding constraint on growth and development in the poorest countries. World Development, 39(1), 33-44.

Olomi, D. R. 2009. From economic necessity to entrepreneurship. In D. R. Olomi (Ed.), African Entrepreneurship and Small Business Development: Context and Process, 46-58, Dar es Salaam, University of Dar es Salaam Press.

Overá, R. (2008). Mobile Traders and Mobile Phones in Ghana. In J. E. Katz (Ed.), Handbook of Mobile Communication Studies, 43-54. Institute of Technology Press Cambridge, MA: Massachusetts

Patton, M. Q. (2002). Qualitative Research and Evaluation Methods, 3rd edn Sage. Thousand Oaks, California.

Porter, G., K. Hampshire, A. Abane, A. Munthali, E. Robson, M. Mashiri, and A. Tanle. 2012. "Youth, mobility and mobile phones in Africa: findings from a threecountry study.” Information Technology for Development, 18(2), 145-162.

Rosa, P. J., Kodithuwakku, S., \& Balunywa, W. (2006). Entrepreneurial motivation in developing countries: What does "necessity" and "opportunity" entrepreneurship really mean? Frontiers of Entrepreneurship Research, 26, 1-14.

Schumpeter, J. A. (1961). The Theory of Economic Development. New York: Oxford University Press.

Singer, S., Amorós, J. E., \& Arreola, M. D. (2015). Global Entrepreneurship Monitor: 2014 Global Report. Global Entrepreneurship Research Association (GERA).

Smallbone, D., \& Welter, F. (2003). Entrepreneurship in Transition Economies: Necessity or Opportunity Driven? Retrieved from https://www.researchgate.net/publication/235966724_Entrepreneurship_in_transi tion_economies_Necessity_or_opportunity_driven. 
Snyder, K. A. (2004). Routes to the informal economy in New York's East Village: Crisis, economics, and identity. Sociological Perspectives, 47(2), 215-240.

Tan, J. (2001). Innovation and risk-taking in a transitional economy: a comparative study of Chinese managers and entrepreneurs. Journal of Business Venturing 16, 359376.

Taormina, R. J., \& Lao, S. K. (2007). Measuring Chinese entrepreneurial motivation: Personality and environmental influences. International Journal of Entrepreneurial Behaviour \& Research, 13(4), 200 - 221.

UNDP (United Nations Development Programme). (2004). Unleashing Entrepreneurship: Making Business Work for the Poor' (report of the Commission on the Private Sector and Development), New York, United Nations Development Programme.

Watson, K., Hogarth-Scott, S., \& Wilson, N. (1998). Small business start-ups: success factors and support implications. International Journal of Entrepreneurial Behaviour and Research, 4(3), 217-38.

Webb, J. W., Bruton, G. D., Tihanyi, L., \& Ireland, R. D. (2013). "Research on entrepreneurship in the informal economy: Framing a research agenda.” Journal of Business Venturing, 28(5), 598-614.

Wennekers, S., \& Thurik, R. (1999). Linking Entrepreneurship and Economic Growth. Small Business Economics, 13(1), 27-55.

Williams, C. C. (2008). Beyond necessity-driven versus opportunity-driven entrepreneurship: A study of informal entrepreneurs in England, Russia and Ukraine. The International Journal of Entrepreneurship and Innovation, 9(3), 157-165.

Williams, C. C., \& Youssef, Y. (2014). Is Informal Sector Entrepreneurship Necessity-or Opportunity-driven? Some Lessons from Urban Brazil. Business and Management Research, 3(1), 41-53.

Xavier, S. R., Kelley, D. J., Kew, J., Herrington, M., \& Vorderwulbecke, A. (2012). Global Entrepreneurship Monitor: 2012 Global Report. Santiago, Universidad del Desarollo.

Yankson, P. W. K., Owusu, G., Gough, K., Osei, R. D. \& Langevang, T. (2011). Global Entrepreneurship Monitor: GEM Ghana 2010 Executive Report. Accra: ISSER.

Yu, F. L. T., \& Kwan, D. S. (2015). African entrepreneurs and international coordination in petty businesses: The case of low-end mobile phones sourcing in Hong Kong. Journal of African Business, 16(1-2), 66-83. 